\title{
Dead on Arrival: The Politics of Budget Making at the Federal Level
}

\begin{abstract}
By Attiat F. Ott ${ }^{*}$
Using Statistics of U.S. federal budget dating back to the 1900's the paper provides a test to a proposition in the political science literature stating that a divided government, where the legislative branch and the executive branch belong to different political parties, give rise to worse political budget policy outcomes than would be the case under a unified government.
\end{abstract}

Keywords: Budget making of the United States federal government. Unified versus divided form of government

"Those who believe that a basic weakness of the United States government is the recurrent conflict and dead lock between the executive and legislative branches must turn, at the outset, to the problem of divided government". Sundquist, 1986 (p.75).

The 2016 Presidential election of Donald Trump and the reshaping of both the U.S. House of Representatives and the U.S. Senate have changed the landscape in the U.S. governing structure. The election changed governance from a divided government, where the president and at least one house of Congress belonged to different parties to a unified government, where the President and both houses of Congress belong to the same party.

Before addressing the politics of budget making at the federal level, especially in light of the dramatic change in governance in the year 2016, it is useful to review briefly the procedure of budget submission.

On the first Monday in February each year, as dictated by law the President submits his annual budget proposal to the U.S. Congress for the coming fiscal year. On February 2016 President Obama submitted his last annual budget to the U.S. Congress, where the President belonged to one political party; the Democratic party, whereas the majority in both chambers; the House and the Senate belonged to the Republican Party, i.e., a divided government.

The new president, President Trump, submitted an outline of his budget for the fiscal year 2018 in March 2017. The budget calls for a level of federal spending of $\$ 4.1$ trillion; $\$ 3.76$ trillion in revenues, and a deficit of $2.3 \%$ of GDP. Deliberations on the President's budget proposal are currently under way. Budget deliberations are quite lengthy, and approval of the budget may be delayed beyond the beginning of the fiscal year. In such event a "continuing" resolution is passed to prevent a government "shutdown". Unlike his predecessor, both

\footnotetext{
${ }^{*}$ Emeritus Professor at Clark University, Worcester Massachusetts, and President of the Institute for Policy Studies, Worcester, Massachusetts, USA.
} 
chambers of Congress belonged to the same party; a unified government, as the President. Hence the expectation is that the 1918 federal budget may be passed before the end of the current fiscal year. As the congress has yet to come up with a budget for fiscal year 2018, below we address issues relating to prior years budgeting.

On the first Monday of February 2016, President Obama submitted his budget proposal to the U.S. Congress. The budget proposal called for $\$ 4.1$ trillion in budget outlays for fiscal year 2017, an increase of $\$ 196.2$ billion in additional discretionary spending above the year 2016; and estimates of $\$ 3,643.7$ trillion in federal revenues in 2017 , with a deficit level of $\$ 503.5$ billion.

"Dead on Arrival" greeted President Obama's budget proposal for 2017. Such a response was not totally unexpected; given the turnover of the legislative branch after the midterm elections in 2015. The results of the mid-term elections took away the Democrats' majority in the U.S. Senate, hence the control of Congress, where both the House and Senate after the mid- term election belonged to the Republican Party.

The early reaction to President Obama's 2017 budget came from the "conservative" corner, with both the House and Senate predicting that the President's budget would be rejected by a majority. Republican leaders in both the House and Senate began to signal that President Obama's budget plan was a "nonstarter".

It is worth noting, that not only does the law states that the President should submit his budget to Congress on the first Monday of February for the upcoming fiscal year, but it also states that Congress should finish its appropriations bills for the upcoming fiscal year by September $30^{\text {th }}$, the end of the previous fiscal year. That does not happen often. In most years, Congress, rather than passing the appropriations bill on time, has relied on "continuing resolutions" to temporarily fund the government for shorter periods or in some cases for the full year. To save time, the 12 required appropriations bills are frequently merged into one bill (the "omnibus" appropriation) or two or three bills ("minibuses") to facilitate passage.

Fiscal year 2017 was no exception. A short term continuing resolution was passed to fund the government through early December, with the outcome of the presidential election then unknown. Once the election had happened, Congress elected to pass a longer continuing resolution through April to allow time for the new Congress and President to have their imprint on the appropriation.

Of note is the fact that since 1974, following the passage of the Budget Reform Act of 1974, Congress has met their appropriations deadline only "four" times, and shut down the government several times. Given that the "Founding Fathers" as Representative Barber Conable put it "did not want efficient, adventurous government" (Conable 1984: 24), a great deal of acrimony between the two branches of government is said to be an outcome of a "divided" government.

This paper investigates the relation between the political makeup of the US government; the legislative and the executive branches of government and the 
federal budget outcomes. In particular, it addresses the notion that a "divided" government produces worse budget outcomes than would be the case under a "unified" government.

An alternative to this proposition, put forth by many, most notably by Niskanen (2006:1) is that a divided government is less "divisive". The underlying philosophy behind such a proposition is that the division of power acts as a restraining influence over the excesses of one party or the other. That is, whenever one party proposes "drastic" or "foolish" measures, the other party can "obstruct" it.

Empirical analyses of the implications of these two alternative forms of government on the federal budget are provided in the paper. For this purpose, I look at budget decisions made by the legislative and executive branches of the federal government as manifest into budget outcomes over the period 19402016. This period is divided into years where both the President and the legislative branches of government (House and Senate) belonged to the same party - unified government and years where there existed a divided government; either the House or the Senate, or both belonged to a different party from that of the President.

Using dummy variables to designate periods of unified government: $U=1 ; 0$ otherwise, I test for the effects of the form of government on the federal budget outcomes.

The paper is structured as follows: Section I begin with some definitions and a brief review of the literature on divided government. Section II provides a look at the statistics for two periods: the years where the same parties held both the executive and congress; unified government); the second is where the President and at least one house; the Senate or the House of Representatives belonged to a different party, divided government. In section III, the hypothesis is stated as well as the methodology used in testing the hypothesis. The results are presented also in this section. Concluding remarks are given in the last section

\section{Divided Government: A Review}

I begin this section by defining what constitutes a divided government. Put simply, a "divided" government is said to take place when different political parties control its functions. In the United States, a divided government exists at the federal level whenever different parties control the three branches of government: the Presidency, the House and the Senate.

"Dead on arrival", the statement that has greeted President Obama's 2017 budget submission to the US Congress, although not new-it has greeted many U.S. Presidents' budgets, would not have taken place under a unified form of government; in other words, if Obama and the majority in both houses of Congress belonged to the same party.

Sundquist noted that: "When government is divided, then the normal and healthy partisan confrontation that occurs during debates in every democratic 
legislature spills over into confrontation between the branches of the government, which may render it immobile." (Sundquist 1986: 78). A similar sentiment was echoed by Douglas Dillon, the former Secretary of the Treasury. According to Dillon: "Our governmental problems do not lie with the quality or character of our elected representatives---rather, "they" lie with a system which promotes divisiveness and makes it difficult, if not impossible, to develop truly national policies" (Dillon 1982: 24).

Sentiments aside, even when explicit delegation was given to the President over the federal budget, as dictated by the Budget Act of 1921, Congress need not consider the President's budget proposal. That is, statements as "dead on arrival" may be uttered. In effect this was evident back in the 1980's from a statement made at a news conference by President Reagan on October 22, 1987, with regard to his budget submission: "every year under the law, I submitted a budget program - and as they've done every year I have been here, they (Congress) put it on the shelf and have refused to even consider it" (President Faces Questions on Budget (1987).

The battle over the budget between the executive and the legislative branches of the federal government is neither won nor lost by one branch. In a divided government the President has many tools under his disposal, such as the veto power, and/or going directly to the voters to gain approval of his budget request. But Congress has powers as well. As we have seen recently, Congress employs threats such as "shutting down" the government to gain concession on budget matters.

The question, though not asked by the ordinary citizen, which most frequently asked by political scientists is: why then a divided form of government?

Going back through US history, it is quite clear that the Founding Fathers did want a divided form of government. Indeed, the separation of powers between the three branches of government is a "corner stone" of the American Constitution. A great deal has changed since 1789; still the framework of separate powers has remained.

The literature about the origin and economic consequences of divided government, both at the federal and state levels is extensive. It was developed mostly by political scientists, notably Fiorina (1992, 2003), Sundquist (1988), Cox and Kernell (1991), Cox and McCubbins (1991), McCubbins (1991), Stewart III (1991) and Mayhew (1991). Their analyses focused mostly on the evolution of divided government and its impact on the "body" politics and political choices. Cox and McCubbins estimated the effects of divided governments on federal tax receipts over the period 1934-1988, whereas Stuart III provided a historical view of partisan control of political institutions over the period 18601930. Fiorina's statistical analyses dealt mostly with divided governments at the states level.

Fiorina is perhaps one of the pioneers who dealt with the issues of divided governments viz à viz unified governments. His analysis, theoretical and empirical was instrumental in providing a clear view of the implications of the form of government on public policy, both at the federal and states levels. Fiorina's 
empirical analyses, however, for the most part dealt with the consequences of divided government at the states level.

At the federal level, Fiorina examined the conformation of appointments process for judicial nominations and for the nominations to executive offices over the period 1933-1988. His findings, suggest that there may have been some "small" degree of increased conflict when different parties control the presidency. The same finding applies to negotiations of "treaties" and "conventions".

McKay (1994) gives a review of few studies on divided government. His review covers both historical and empirical analysis of the working of, as well as, the implications of divided government at both the federal and the states levels.

According to McKay, scholars addressing the question of divided government have taken two distinct approaches to the issue: one approach is said to be "essentially prescriptive"; the other is "more inductive and analytical" (McKay 1994: 525). The first school of thought assumes that the divided government structure is not an outcome of voting but rather of a constitutional structure. As such to change the form of government, the constitutional structure has to change.

In the context of the federal government, the Founding Fathers is said to have created a "tripartite" system of independent yet interdependent branchesexecutive, legislative and judicial; hence if divided government were to yield "bad" outcomes, then a "Constitutional" amendment is needed to alter the structure (Sandquist 1986). As many would recall, efforts to pass a "Constitutional Amendment" to balance the federal budget have repeatedly failed. This is in contrast with public opinion survey data which shows an overwhelming majority of citizens $(70 \%)$ favor a constitutional amendment to balance the budget (Jacobson, 1990, p.300).

The alternative school of thought according to McKay (1994) employs data and empirical analyses to uncover the consequences of divided government, both at the federal and state levels (Fiorina 2003), McCubbins (1991), Cox and McCubbins (1991) and Stewart III (1991). Below, a brief review is presented of the findings of these studies as they relate to divided government at the federal level.

The study by McCubbins (1991) provides data on the effect of party control of congress on appropriation bills submitted by the executive. Looking at data covering the period 1948-1985, he calculated the percentage changes in budget requests for domestic agencies during the terms of six presidents: Truman, Eisenhower, Kennedy/Johnson, Nixon/Ford, Carter and Reagan. His calculations show that the range of the mean percentage changes in appropriations varied from less than $1 \%$ for Reagan, to over $17 \%$ for Truman. For the other four, it was around $11 \%$.

When the change in appropriations was calculated by party control of Congress, McCubbins reported that under Republican control, the change in appropriations averaged $58 \%$, but the change equaled $83 \%$ under Democratic control. On the other hand, appropriations that were less than the previous year amounted to $42 \%$ under the Republican, but some $17 \%$ under Democrats. As McCubbins put it: when the "Republicans controlled both houses of Congress 
(1947- 1948, and 1953-1954), the result was a cut in appropriations by $42 \%$." This finding is contrasted with the actions of Democrats controlling both houses of Congress. As reported, earlier, under Democratic control of both houses, appropriations were cut by only $17 \%$, suggesting that the two parties do indeed differ when it comes to budget formulation (McCubbins 1991: 123).

Cox and McCubbins provide statistical analyses of the pattern of federal tax receipts under divided government. Using data on annual federal tax receipts and GDP over the period 1934-1989 (both series for fiscal years, converted to constant dollars using the implicit price deflator for federal purchases and GNP price deflator), they tested for the effect of partisan control on federal receipts.

Their findings suggest that under divided control, where the President belonged to the Democratic Party, and where both houses were controlled by the Republican Party, everything there was a negative effect on federal tax receipts. On the other hand, when the President belonged to the Republican party, but the Republicans did not hold majority in both houses of Congress, the reduction in tax receipts was quite "small" (Cox and McCubbins 1991: 169) ${ }^{1}$.

Stewart's study focused on the effects of "partisan" division on public policy during the early $19^{\text {th }}$ century. According to Stewart III, two issues of contentions between the Republicans and the Democrats were "tariffs" and the "federal budget": taxes and spending. Using data covering the period 18501920, Stewart analyses of the data led him to conclude that the "persistence" of divided government following the "reconstruction" had a lasting impact on policy making at the federal level (199: 217). Hence, there arose, a sharp partisan division about federal spending and taxes.

An insight gleaned from Stewart's analyses, is that differences between the two parties in the early $19^{\text {th }}$ century on budget policies were rooted in differences in their "constituency bases". Moreover, contrary to the budget posture in the twentieth and twenty first centuries, one is struck by his finding that, divided government late in the $19^{\text {th }}$ century, was associated with budget surpluses rather than budget deficits.

\section{Unified and Divided Governments: A look at the Data}

Updating and expanding on the knowledge reviewed above, the following section, presents data analyses of the federal budget receipts, outlays and the public debt, to uncover the effects of divided government on budget outcomes. The data analyses, spanning a period of seventy six (76) years, hopefully will complement the knowledge gained from earlier studies. The two variables of interest are: the federal budget receipts and the federal budget outlays. The federal debt is viewed here as an endogenous variable, the outcome of decisions by both the President and Congress about the state of the economy.

A note about the federal budget statistics reported below: Historical data on federal budget receipts and outlays are provided annually over the period 
1901-2016, in the Historical Statistics of the Federal Government (The Budget for Fiscal year 2013, Historical Tables). However, the data for the public debt is given annually only for the 1940-2016 period. Accordingly, the budget data presented in the Tables and Figures covers the period 1940-2016. Data on the control of the federal government; unified and divided is given for the period 1901-2016 to provide a historical perspective about the control of the federal government.

\section{The Data}

This section begins by providing information on the structure of the federal government; unified and divided, dating back to the 1900's. The following definitions and symbols are used:

- Unified government is where: the President $(\mathrm{P})$; Congress: Senate $(\mathrm{S})$ and House $(\mathrm{H})$ are of the same party.

- Divided government is where: the President $(\mathrm{P})$ is from one party, Congress: Senate $(\mathrm{S})$ and/or House $(\mathrm{H})$ are from different parties.

Identification of party control over the period 1911-2016 is given in Table 1. The first part of the table (part A) gives the information for unified government; the second part (part $B$ ) is for divided government.

The data reported in Table 1(A) and 1(B), Shows that over a period of 116 years, the federal government was under unified control for 66 years, and divided control for 50 years. As the data in Table (1A) shows under unified control, the Democrats seem to have dominated the control of government: 40 to 26 . The break point occurred around the mid 1930's where the Democrats won both the executive and the legislative branches of government: 34 to 6 .

When the control of government was divided, Table (1B) the picture altered greatly: The Republicans were able to control the Presidency 34 to 16, the Senate 36 to 14, although the House democrats retained their dominance: 34 to 16 .

The data thus far about the division of the control of the Presidency between Democrats and Republicans (60 to 56) seems to suggest that at least at the presidential level no form of government had more voters' appeal than the other. As to the control of the legislative branch, there seems to be a difference in voter's preferences for the control of the two houses. In periods of divided government, voters' preference favored Republicans in the Senate and Democrats in the House. 
Vol. 4, No. 1 Ott: Dead on Arrival: The Politics of Budget Making at the Federal Level

Table 1. Party Control of the Executive and Legislative Branches of the Federal Government, 1901-2016

A. Unified Control

\begin{tabular}{lcc}
\hline $\begin{array}{l}\text { Year } \\
\text { Democrats }\end{array}$ & Unified Republicans & Unified \\
\hline $1901-1910$ & 10 & 0 \\
$1913-1918$ & 0 & 6 \\
$1921-1930$ & 10 & 0 \\
$1933-1946$ & 0 & 14 \\
$1949-1952$ & 0 & 4 \\
$1953-1954$ & 2 & 0 \\
$1961-1968$ & 0 & 8 \\
$1977-1980$ & 0 & 4 \\
$1993-1994$ & 0 & 2 \\
$2003-2006$ & 4 & 0 \\
$2009-2010$ & 0 & 2 \\
\hline $1901-2016$ & 26 & 40
\end{tabular}

Total $=66$, Republicans $=26$, Democrats $=40$

B. Divided Control

\begin{tabular}{lccc}
\hline Year & President & Senate & House \\
\hline $1911-1913$ & $\mathrm{R}(2)$ & $\mathrm{R}(2)$ & $\mathrm{D}(2)$ \\
$1919-1921$ & $\mathrm{D}(2)$ & $\mathrm{R}(2)$ & $\mathrm{D}(2)$ \\
$1931-1933$ & $\mathrm{R}(2)$ & $\mathrm{R}(2)$ & $\mathrm{D}(2)$ \\
$1947-1949$ & $\mathrm{D}(2)$ & $\mathrm{R}(2)$ & $\mathrm{R}(2)$ \\
$1955-1960$ & $\mathrm{R}(6)$ & $\mathrm{R}(6)$ & $\mathrm{D}(6)$ \\
$1969-1976$ & $\mathrm{R}(8)$ & $\mathrm{R}(8)$ & $\mathrm{D}(8)$ \\
$1981-1986$ & $\mathrm{R}(6)$ & $\mathrm{R}(6)$ & $\mathrm{D}(6)$ \\
$1987-1992$ & $\mathrm{R}(6)$ & $\mathrm{D}(6)$ & $\mathrm{D}(6)$ \\
$1995-2000$ & $\mathrm{D}(6)$ & $\mathrm{R}(6)$ & $\mathrm{R}(6)$ \\
$2001-2002$ & $\mathrm{R}(2)$ & $\mathrm{D}(2)$ & $\mathrm{R}(2)$ \\
$2007-2008$ & $\mathrm{R}(2)$ & $\mathrm{D}(2)$ & $\mathrm{D}(2)$ \\
$2011-2014$ & $\mathrm{D}(4)$ & $\mathrm{D}(4)$ & $\mathrm{R}(4)$ \\
$2015-2016$ & $\mathrm{D}(2)$ & $\mathrm{R}(2)$ & $\mathrm{R}(2)$ \\
\hline
\end{tabular}

Republican Presidents $=34$, Senate $=36$, House $=16$

Democrat Presidents $=16$, Senate $=14$, House $=34$

Source: Composition of Congress, by Political Party, 1855-2017, Office of the Clerk of the

House of Representative.

When viewed in the context of the literature, the data presented in the tables (Table 2A and Table 2B) suggests that differences are likely to exist in budget outcomes under unified versus divided governments. Because budget policy is not made in a vacuum, but rather is influenced by the state of the economy, the budget data presented in the tables is given in relation to GDP.

The data in the tables shows a great deal of variations under both unified and divided governments through the period 1940-2016. Aside from the war years, which necessitated borrowing to cover war related expenses; the public debt as per cent of GDP more than doubled over the period 1940-1946, government receipts and outlays as percentages of GDP rose as well. As the data in Table 2A 
shows, the rise in expenditures was twice as large as that of receipts over the same period.

Table 2a. Change in Federal Government Finance

\begin{tabular}{lcccccc}
\multicolumn{7}{c}{ Unified Government } \\
\hline Year & President & Senate & House & $\begin{array}{c}\text { Debt } \\
\text { \% of GDP }\end{array}$ & $\begin{array}{c}\text { Receipts } \\
\text { \% of GDP }\end{array}$ & $\begin{array}{c}\text { Outlays } \\
\text { \% of GDP }\end{array}$ \\
1940 & D & D & D & 44.2 & 6.8 & 9.8 \\
1941 & D & D & D & 42.3 & 7.6 & 12.0 \\
1942 & D & D & D & 47.0 & 10.1 & 24.3 \\
1943 & D & D & D & 70.9 & 13.3 & 43.6 \\
1944 & D & D & D & 88.3 & 20.9 & 43.6 \\
1945 & D & D & D & 106.2 & 20.4 & 41.9 \\
1946 & D & D & D & 108.7 & 17.7 & 24.8 \\
1949 & D & D & D & 79.0 & 14.5 & 14.3 \\
1950 & D & D & D & 80.0 & 14.4 & 15.6 \\
1951 & D & D & D & 66.9 & 16.1 & 14.2 \\
1952 & D & D & D & 61.6 & 19.0 & 19.4 \\
1953 & R & R & R & 58.6 & 18.7 & 20.4 \\
1954 & R & R & R & 59.5 & 18.5 & 18.8 \\
1961 & D & D & D & 45.0 & 17.8 & 18.4 \\
1962 & D & D & D & 43.7 & 17.6 & 18.8 \\
1963 & D & D & D & 42.4 & 17.8 & 18.6 \\
1964 & D & D & D & 40.0 & 17.6 & 18.5 \\
1965 & D & D & D & 37.9 & 17.0 & 17.2 \\
1966 & D & D & D & 34.9 & 17.3 & 17.8 \\
1967 & D & D & D & 32.9 & 18.4 & 19.4 \\
1968 & D & D & D & 33.3 & 17.6 & 20.5 \\
1977 & D & D & D & 27.8 & 18.0 & 20.7 \\
1978 & D & D & D & 27.4 & 18.0 & 20.7 \\
1979 & D & D & D & 25.6 & 18.5 & 20.1 \\
1980 & D & D & D & 26.1 & 19.0 & 21.7 \\
1993 & D & D & D & 49.3 & 17.5 & 21.4 \\
1994 & D & D & D & 49.2 & 18.0 & 21.0 \\
2003 & R & R & R & 35.6 & 16.2 & 19.7 \\
2004 & R & R & R & 36.8 & 16.1 & 19.6 \\
2005 & R & R & R & 36.9 & 17.3 & 19.9 \\
2006 & R & R & R & 36.0 & 18.2 & 20.1 \\
2009 & D & D & D & 54.1 & 15.1 & 25.2 \\
2010 & D & D & D & 62.8 & 15.1 & 24.1
\end{tabular}


Vol. 4, No. 1 Ott: Dead on Arrival: The Politics of Budget Making at the Federal Level

Table 2b. Change in Federal Government Finance Divided Government

\begin{tabular}{|c|c|c|c|c|c|c|}
\hline Year & President & Senate & House & $\begin{array}{c}\text { Debt } \\
\% \text { of GDP }\end{array}$ & $\begin{array}{l}\text { Receipts } \\
\% \text { of GDP }\end{array}$ & $\begin{array}{r}\text { Outlays } \\
\% \text { of GDP }\end{array}$ \\
\hline 1947 & D & $\mathrm{R}$ & $\mathrm{R}$ & 96.2 & 16.5 & 14.8 \\
\hline 1948 & $\mathrm{D}$ & $\mathrm{R}$ & $\mathrm{R}$ & 84.3 & 16.2 & 11.6 \\
\hline 1955 & $\mathrm{R}$ & $\mathrm{R}$ & $\mathrm{D}$ & 57.2 & 16.5 & 17.3 \\
\hline 1956 & $\mathrm{R}$ & $\mathrm{R}$ & D & 52.0 & 17.5 & 16.5 \\
\hline 1957 & $\mathrm{R}$ & $\mathrm{R}$ & D & 48.6 & 17.7 & 17.0 \\
\hline 1958 & $\mathrm{R}$ & $\mathrm{R}$ & D & 49.2 & 17.3 & 17.9 \\
\hline 1959 & $\mathrm{R}$ & $\mathrm{R}$ & $\mathrm{D}$ & 47.9 & 16.2 & 18.8 \\
\hline 1960 & $\mathrm{R}$ & $\mathrm{R}$ & $\mathrm{D}$ & 45.6 & 17.8 & 17.8 \\
\hline 1969 & $\mathrm{R}$ & $\mathrm{R}$ & D & 29.3 & 19.7 & 19.4 \\
\hline 1970 & $\mathrm{R}$ & $\mathrm{R}$ & D & 28.0 & 19.0 & 19.3 \\
\hline 1971 & $\mathrm{R}$ & $\mathrm{R}$ & D & 28.1 & 17.3 & 19.5 \\
\hline 1972 & $\mathrm{R}$ & $\mathrm{R}$ & D & 27.4 & 17.6 & 19.6 \\
\hline 1973 & $\mathrm{R}$ & $\mathrm{R}$ & D & 26.0 & 17.6 & 18.7 \\
\hline 1974 & $\mathrm{R}$ & $\mathrm{R}$ & D & 23.9 & 18.3 & 18.7 \\
\hline 1975 & $\mathrm{R}$ & $\mathrm{R}$ & D & 25.3 & 17.9 & 21.3 \\
\hline 1976 & $\mathrm{R}$ & $\mathrm{R}$ & $\mathrm{D}$ & 27.5 & 17.1 & 21.4 \\
\hline 1981 & $\mathrm{R}$ & $\mathrm{R}$ & $\mathrm{D}$ & 25.8 & 19.6 & 22.2 \\
\hline 1982 & $\mathrm{R}$ & $\mathrm{R}$ & $\mathrm{D}$ & 28.7 & 19.2 & 23.1 \\
\hline 1983 & $\mathrm{R}$ & $\mathrm{R}$ & $\mathrm{D}$ & 33.1 & 17.5 & 23.5 \\
\hline 1984 & $\mathrm{R}$ & $\mathrm{R}$ & $\mathrm{D}$ & 34.0 & 17.3 & 22.2 \\
\hline 1985 & $\mathrm{R}$ & $\mathrm{R}$ & $\mathrm{D}$ & 36.4 & 17.7 & 22.8 \\
\hline 1986 & $\mathrm{R}$ & $\mathrm{R}$ & $\mathrm{D}$ & 39.5 & 17.5 & 22.5 \\
\hline 1987 & $\mathrm{R}$ & $\mathrm{D}$ & $\mathrm{D}$ & 40.6 & 18.4 & 21.6 \\
\hline 1988 & $\mathrm{R}$ & $\mathrm{D}$ & $\mathrm{D}$ & 41.0 & 18.2 & 21.3 \\
\hline 1989 & $\mathrm{R}$ & $\mathrm{D}$ & $\mathrm{D}$ & 40.6 & 18.4 & 21.2 \\
\hline 1990 & $\mathrm{R}$ & $\mathrm{D}$ & $\mathrm{D}$ & 42.1 & 18.0 & 21.9 \\
\hline 1991 & $\mathrm{R}$ & $\mathrm{D}$ & $\mathrm{D}$ & 45.3 & 17.8 & 22.3 \\
\hline 1992 & $\mathrm{R}$ & $\mathrm{D}$ & $\mathrm{D}$ & 48.1 & 17.5 & 22.1 \\
\hline 1995 & $\mathrm{D}$ & $\mathrm{R}$ & $\mathrm{R}$ & 49.1 & 18.4 & 20.6 \\
\hline 1996 & $\mathrm{D}$ & $\mathrm{R}$ & $\mathrm{R}$ & 48.4 & 18.8 & 20.2 \\
\hline 1997 & $\mathrm{D}$ & $\mathrm{R}$ & $\mathrm{R}$ & 45.9 & 19.2 & 19.5 \\
\hline 1998 & $\mathrm{D}$ & $\mathrm{R}$ & $\mathrm{R}$ & 43.0 & 19.9 & 19.1 \\
\hline 1999 & $\mathrm{D}$ & $\mathrm{R}$ & $\mathrm{R}$ & 39.4 & 19.8 & 18.5 \\
\hline 2000 & $\mathrm{D}$ & $\mathrm{R}$ & $\mathrm{R}$ & 34.7 & 20.6 & 18.2 \\
\hline 2001 & $\mathrm{R}$ & $\mathrm{D}$ & $\mathrm{R}$ & 32.5 & 19.5 & 18.2 \\
\hline 2002 & $\mathrm{R}$ & D & $\mathrm{R}$ & 33.6 & 17.6 & 19.1 \\
\hline 2007 & $\mathrm{R}$ & D & D & 36.3 & 18.5 & 19.7 \\
\hline 2008 & $\mathrm{R}$ & D & D & 40.5 & 17.6 & 20.8 \\
\hline 2011 & D & D & $\mathrm{R}$ & 67.7 & 15.4 & 24.1 \\
\hline $2012 *$ & $\mathrm{D}$ & $\mathrm{D}$ & $\mathrm{R}$ & 74.2 & 15.8 & 24.3 \\
\hline $2013 *$ & $\mathrm{D}$ & $\mathrm{D}$ & $\mathrm{R}$ & 77.4 & 17.8 & 23.3 \\
\hline $2014 *$ & $\mathrm{D}$ & $\mathrm{D}$ & $\mathrm{R}$ & 78.4 & 18.7 & 22.6 \\
\hline $2015^{*}$ & $\mathrm{D}$ & $\mathrm{R}$ & $\mathrm{R}$ & 78.1 & 19.0 & 22.3 \\
\hline $2016^{*}$ & $\mathrm{D}$ & $\mathrm{R}$ & $\mathrm{R}$ & 77.8 & 19.1 & 22.5 \\
\hline
\end{tabular}


Under unified government, both receipts and outlays over the period, seem to stabilize around 18-20 per cent of GDP, with the exception of the years 2009 and 2010 , where receipts fell dramatically to $15 \%$ of GDP, while outlays rose to a quarter $(25 \%)$ of GDP. Similarly, the public debt which began its slide downwards reaching a quarter of GDP in 1979 more than doubled in 2009 while government outlays kept on rising, receipts falling .

The picture differs somewhat in the years when the Federal government was under divided control; outlays rose steadily since the mid-seventies, from $18.7 \%$ to $22.8 \%$ by the mid 1980 's, as to receipts, it fluctuated rising and falling by some 2 percentage points of GDP throughout the 1980's. During the 1990's and early 2000's outlays began to fall while both receipts and the public debt kept on rising.

Table 3. Federal Budget Posture under Unified Government and Divided Government, 1947-2016 (Percent Change)

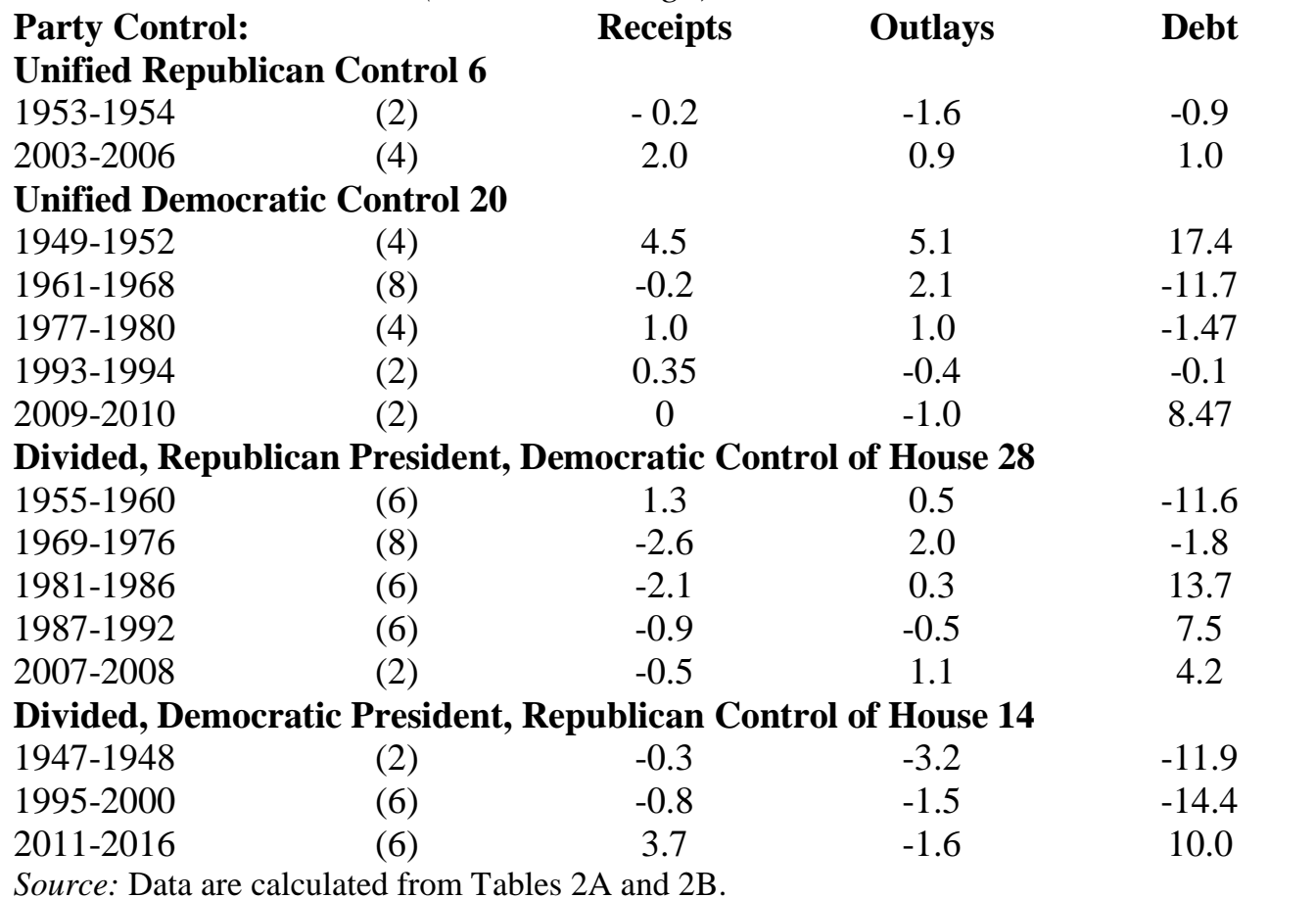

The data reported in Table 3, summarizes the information given in Table 2, by focusing on the "changes" in the values of the variables under the two systems of government régimes. The first part of the table, gives percentage changes in the values of the variables under unified government; the second part presents the data under divided government. In the table, under divided government, the data presented is arranged by Presidential control and the control of the House of Representatives. The years 1940-1946 were not included in the analyses to eliminate the war effect.

At a glance, it is clear from the data in the table, that over the period 19492016, the Federal government was under divided control for twice as long as under unified control -26 years to 42 . In the first period of unified Republican 
control 1953-1954, both receipts and outlays show a decline whereas the public debt showed a small increase. In the second period of unified Republican control, 2003-2006 all magnitudes showed an increase with the largest increase is recorded for receipts.

Under unified Democratic control lasting for a 20 years period, the most notable change is the continued decline (except for the later period, 2009-2010) in the public debt. The negative change in receipts along with the rise in expenditure was designed for stabilizing the national economy.

Periods of divided control under a Republican President and a Democratic control of the House, one discerns a continued fall in receipts, with the largest decline recorded in 1967-1976 following the tax cut of 1969. The percentage changes in outlays show an increase during the 1969-1976 period, although the debt fell by 1.8 per cent. The percentage change in receipts continued its fall in the following periods, while both outlays (except for 1987-1992) and the public debt showed increase.

Finally, a look at the control of the Federal government, where the Presidency was in the hands of the Democratic Party, but the House was under Republican control. During a 14 years period, most of which falling in the mid1990 and during the latest period 2011-2016, the data shows a change in the behavior of the variables, in particular outlays.

As shown in the table, over the two periods, 1947-1948; 1995-2000, a Republican controlled house led to a reduction in the magnitudes of all three variables. The later period 2011-2016, the budget estimates show a small fall in outlays but a significant rise in both receipts and the public debt.

Figures 1 and 2 supplement the data reported in the tables. Figure 1 is a plot of percent change in government receipts (calculated in constant dollars), whereas Figure 2 plots the percent change in Government outlays, also in constant dollars. As may be seen from the figures, there has been a great deal of fluctuations in government receipts throughout the period compared to government outlays.

Although the data presented in both the tables and figures are useful for the purpose of ascertaining changes in the federal budget posture under the two types of control, it fails to give us a clear distinction about the budget ideology under a unified government control as compared to a divided control, a point of contention among many. To shed some light on this, a model was estimated using dummy variables to designate the type of governmental control of the federal government. 
Figure 1. Percent Change in Government Receipt (Constant dollars)

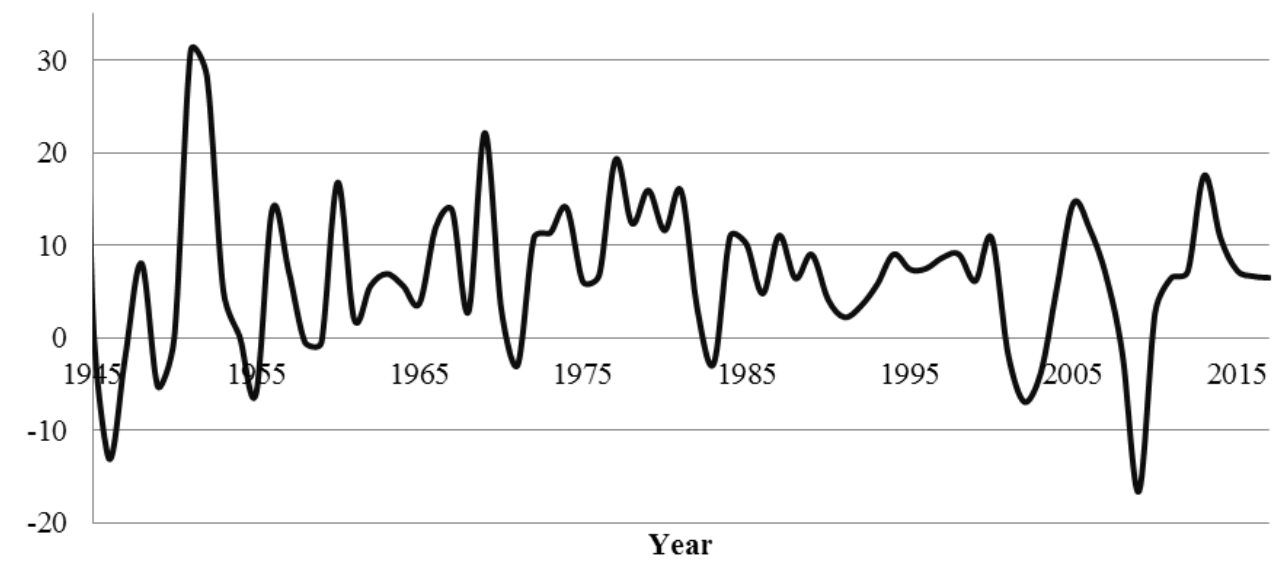

Figure 2. Percent Change in Government Outlays (Constant dollars)

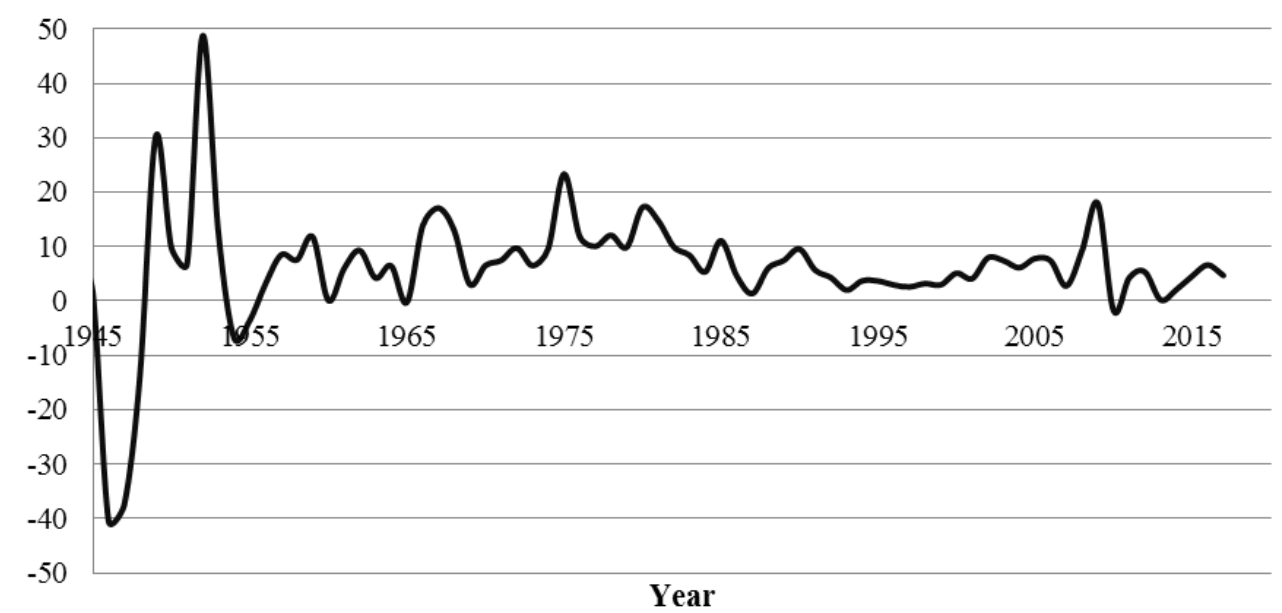

\section{The Model}

The empirical model used is a binary, or a dummy variable model. A comparison of the relevant variables; Federal budget receipts, and Federal budget outlays in the two forms of governments; Unified and Divided is formulated as:

Unified: $\quad y_{i}=\mu+\delta$

Divided: $\quad y_{i}=\mu+\delta+\varepsilon_{i}$

Defining the variable $=1$ for Unified, and $=0$ for Divided, we have the following equation: $y_{i}=\mu+\delta \cdot d_{i}+\varepsilon_{i}$.

- The null hypothesis: An observed difference in receipts to GDP (T/GDP), outlays to GDP (G/ GDP) reflects chance variations.

- The alternative hypothesis is that the observed difference is real.

Significance level $p=1 \%$, or $5 \%$. 
The model tests for differences in the values of the above magnitudes under different control of the Federal government. In the regression model, party control is identified as: Unified control is when the President and both houses of Congress belong to the same party; divided control is when the President belongs to one party, and at least one house of Congress belongs to another party. The estimated equation is as follows:

$\Delta R=f(U, \quad W W I I, \quad R(t-1), \quad G D P(t-1))$

and,

$\Delta G=f(U, \quad W W I I, \quad G(t-1), \quad G D P(t-1))$

\section{Results}

The results for the estimated equations for the change in receipts and outlays are given in Tables 4 and 5. Because of the large fluctuations in the data (see Figures 1 and 2), the model was estimated with and without logarithms.

The regression results were not totally unexpected. The data reported in Table 3, discussed earlier, suggests that differences in budget policies, with regards to setting receipts and outlays were not quite large enough to validate the notion that federal budget posture is critically dependent on the form of government. This inference was validated to some extent by the regression results.

Table 4. Regression Model Results

\begin{tabular}{lcc}
\hline & $(1)$ & $(2)$ \\
& change $\mathrm{R}$ & change_G \\
L.receipts & $-0.506 * * *$ & \\
& $(-3.85)$ & -5.692 \\
unified & -45.00 & $(-0.14)$ \\
& $(-1.95)$ & $324.3 *$ \\
wwII & -3.920 & $(2.46)$ \\
& $(-0.07)$ & 0.0344 \\
L.gdp & $0.440^{* * *}$ & $(0.30)$ \\
& $(5.63)$ & 0.129 \\
L2.gdp & $-0.337 * *$ & $(0.66)$ \\
& $(-3.16)$ & -0.239 \\
L3.gdp & 0.0223 & $(-1.22)$ \\
& $(0.21)$ & 0.213 \\
L4.gdp & -0.0399 & $(1.83)$ \\
& $(-0.57)$ & \\
L.outlays & $-0.541 * * *$ & $-103.1 *$ \\
& $(-4.91)$ & $(-2.10)$ \\
Constant & 15.32 & 74 \\
Observations & $(0.60)$ & 0.323 \\
R-squared & 74 & \\
t statistics in parentheses & 0.372 & \\
* p $<0.05, * * \mathrm{p}<0.01, * * * \mathrm{p}<0.001$ & &
\end{tabular}


The model estimates for federal budget receipts reported in Tables 4 and 5 do not reject the null hypothesis. The dummy variable $\mathrm{U}$, for unified government did not turn out to be significant at either the $p<0.05, p<0.01$. The results differed with respect to federal budget outlays.

As shown in the tables, when the model was estimated with the logarithm of the variables, the form of government turned out to be very significant $(p<0.01)$.

The findings reported above, support but weakly the contention that the form of government has implications for federal budget polices. This finding, none-withstanding, should not be construed to mean that ideology does not impact budget making at the federal level. The weak evidence may perhaps be the results of aggregation. Difference in ideologies espoused by members of the legislative and the executive branches of the federal government, whether under divided or unified government may not be captured by looking at budget aggregates. What are missing are the micro foundations of these aggregates. Disaggregating the data perhaps, one may be able to capture how the type of government influences budget outcomes.

Table 5. Regression Model Results (with logarithms)

\begin{tabular}{|l|c|c|}
\hline & $\begin{array}{c}(\mathbf{1}) \\
\text { In_change R }\end{array}$ & $\begin{array}{c}(\mathbf{2}) \\
\text { In_change_G }\end{array}$ \\
\hline L.ln_r & $-4.635^{* *}$ & \\
\hline \multirow{2}{*}{ unified } & $-3.02)$ & $0.899^{* *}$ \\
& $(-1.294$ & $(2.96)$ \\
\hline \multirow{2}{*}{ wwII } & -0.540 & $2.963^{*}$ \\
& $(-0.56)$ & $(2.31)$ \\
\hline \multirow{2}{*}{ L.ln_y } & $14.48^{* *}$ & 1.836 \\
& $(3.31)$ & $(0.49)$ \\
\hline \multirow{2}{*}{ L2.ln_y } & -3.078 & -0.305 \\
& $(-0.67)$ & $(-0.05)$ \\
\hline \multirow{2}{*}{ L3.ln_y } & -5.192 & 7.441 \\
& $(-0.86)$ & $-5.25)$ \\
\hline \multirow{2}{*}{ L4.ln_y } & -0.683 & $(-1.30)$ \\
\hline \multirow{2}{*}{ L.ln_g } & $(-0.17)$ & $-1.998^{* *}$ \\
& & $(-3.07)$ \\
\hline Constant & & $-8.851^{* *}$ \\
& $(-2.96)$ \\
\hline Observations & $-12.15^{* *}$ & 58 \\
\hline R-squared & $(-3.34)$ & 0.395 \\
\hline
\end{tabular}

$\mathrm{t}$ statistics in parentheses

$* \mathrm{p}<0.05, * * \mathrm{p}<0.01, * * * \mathrm{p}<0.001$

\section{Concluding Remarks}

"Dead on arrival" or a statement just like it, often greets a President's blueprint for the nation's economy. Such open skepticism about a President's 
budget program, led some scholars to suggest that a reaction as this deserves a search for the root causes of such skepticism, especially when the phrase most often is uttered by some members of the opposing political party.

The reception with which President' Obama 2017 budget submission to the nation was received, is neither novel nor new. Many Presidents' budget submissions, both in the Republican camp as well as the Democratic camp, have received similar reaction leading to delays in the passage of the nation's budget. Often enough, rather than acting on the President's budget request, Congress seemed to be addicted to substitute a President' request for budget spending, by a "Continuing Resolution", thus replacing the appropriations requested by the President for Federal Agencies, to avoid the shutdown of the federal government.

The political science literature offers us a window on the conflicts that often arise between the two branches of government; the executive and the legislative on several matters, from budget allocation and tax policy to the confirmation of presidential appointments and the negotiation of treaties. Some political scientists went as far as to suggest that the current separation of powers be modified. As discussed above, Sundquist is not only an ardent critic of the current system of governance that gave rise to divided government, but also goes as far as to suggest several "constitutional" changes to the constitutional structure of separate branches of government which in his views gave rise to a divided form of governance.

Although the theoretical literature reviewed earlier in the paper, has identified some problems with a divided form of government, when combined with empirical findings cast a shadow on the notion that divided government give rise to worse budget outcomes at the Federal level than would be the case under a unified government.

The empirical literature available thus far conveys but a marginal effect of unified government on the federal budget outcomes. Our findings presented above, of the effect of party control on federal budget policy carried out over a period of seventy years (from 1947-2016), fail to support the notion that budget outcomes at the Federal level under a unified government, differ significantly from those under a divided control of the federal government.

In effect, the empirical analysis presented above shows no difference in federal budget receipts under a unified control as opposed to a divided control of the federal government. As to government outlays, a strong effect was found suggesting that the two forms of government do indeed differ.

Over the next "four" years, with the U.S. election of representatives in both the legislative and the executive branches of the federal government, the findings reported above may be put to the empirical test. That is, if a unified form of government was to continue, then the expectation would be that federal spending is much more likely than federal taxes to follow a lower path. As to the path of federal taxes, the data analyses suggest that the path may not be significantly altered. 


\section{Acknowledgements}

I wish to thank Drs. Dana Ott, Mike Johnson for their valuable Comments. Dr. Nicole Bissessar helped with the regression analyses.

\section{References}

Conable B (1984) "Roll Call" Reprinted in The Constitution: A Bicentennial Chronicle Winter: 42-43.

Cox GW, Kernell S (1991) (eds) The Politics of Divided Government, Boulder.

Cox G. W. and McCubbins M.D., (1991) “Divided control of Fiscal Policy', in Cox and Kernell, (1991): 157-172.

Dillon D (May 30, 1982) Address at Tufts University. Reprinted in DL Robinson (ed) Reforming American Government: The Bicentennial Papers of the Committee on the Constitutional System, Boulder (1985), 24- 29.

Fiorina MP (2003) Divided Government, $2^{\text {nd }}$ ed., New York: Pearson.

Fiorina, MP (1992) Divided Government. New York: Pearson.

Mayhew DR (1991) Divided we Govern: Party Control. Law Makings and Investigations 1946-1990. New Haven.

McCubbins MD (1991) Government on Lay-Away, Federal Spending and Deficits under Divided Party Control in GW Cox and S Kernell (eds), Boulder, 113-150.

McKay D (1994) Divided and Governed? Recent Research on Divided Government in the United States. British Journal of Political Science 24(4): 516-534.

Niskanen W (2015) Divided Government, February 16.

"President Faces Questions on Budget, Persian Gulf Policies" (1987), Congressional Quarterly Weekly Report 45, 1987: 2626.

Sundquist JL (1987) Constitutional Reform and Effective Government. Washington D.C: The Brookings Institution.

CH Stewart III (1991) Lessons from The Post- Civil War Era. In Cox and Kernelled: 203236. 
